\title{
Effect of surface modification and oxygen deficiency on intercalation property of lithium nickel manganese oxide in an all-solid-state battery
}

Gwangseok Oh, Masaaki Hirayama*, Ohmin Kwon, Kota Suzuki, and Ryoji Kanno

Tokyo Institute of Technology, G1-1, 4259, Nagatsuda, Midoriku, Yokohama, 2268502, Japan

*Corresponding author, TEL: +81-45-924-5403, Fax: +81-45-924-5403, e-mail: hitrayama@echem.titech.ac.jp

Keywords: $\mathrm{LiNi}_{0.5} \mathrm{Mn}_{1.5} \mathrm{O}_{4}$; Sulfide electrolyte; Surface coating; $\mathrm{Li}_{10} \mathrm{GeP}_{2} \mathrm{~S}_{12}$; Lithium intercalation

\begin{abstract}
$\mathrm{LiNbO}_{3}$-coated $\mathrm{LiNi}_{0.5} \mathrm{Mn}_{1.5} \mathrm{O}_{4}$ powders were synthesized by a sol-gel method, and their intercalation property as a cathode material was investigated using all-solidstate batteries with $\mathrm{Li}_{10} \mathrm{GeP}_{2} \mathrm{~S}_{12}$ solid electrolyte and In-Li metal anode. The $\mathrm{LiNbO}_{3}$ coating delivered reversible lithium intercalation of $\mathrm{LiNi}_{0.5} \mathrm{Mn}_{1.5} \mathrm{O}_{4}$ through an electrochemical interface with the $\mathrm{Li}_{10} \mathrm{GeP}_{2} \mathrm{~S}_{12}$. Oxygen-deficient $\mathrm{LiNi}_{0.5} \mathrm{Mn}_{1.5} \mathrm{O}_{4-\delta}$ with a higher electronic conductivity than $\mathrm{LiNi}_{0.5} \mathrm{Mn}_{1.5} \mathrm{O}_{4}$ improved the intercalation
\end{abstract}


activity. An all-solid-state battery consisting of 3 wt.\%- $\mathrm{LiNbO}_{3}$-coated $\mathrm{LiNi}_{0.5} \mathrm{Mn}_{1.5} \mathrm{O}_{4}$ $\delta / \mathrm{Li}_{10} \mathrm{GeP}_{2} \mathrm{~S}_{12} / \mathrm{In}-\mathrm{Li}$ exhibited a discharge capacity of $80 \mathrm{mAh} \mathrm{g}^{-1}$ at the first cycle with an average discharge voltage of $4.1 \mathrm{~V}$ (vs. In-Li), which demonstrates the possibility of $5 \mathrm{~V}$ class all-solid-state batteries with a high voltage spinel cathode.

\section{Introduction}

Lithium ion batteries with high power and energy densities are being intensively investigated for use in new applications such as hybrid electric and electric vehicles. However, safety precautions are strictly required for such largescale systems due to the flammable organic liquids that are used as the electrolyte. All-solid-state batteries with a nonflammable solid electrolyte have recently attracted growing interest due to their high stability. Another advantage of solid electrolytes is the wide electrochemical window over $5 \mathrm{~V}\left(v s . \mathrm{Li} / \mathrm{Li}^{+}\right)$compared to organic liquid electrolytes, which enables the use of high-voltage cathodes for highenergy-density batteries [1].

$\mathrm{LiNi}_{0.5} \mathrm{Mn}_{1.5} \mathrm{O}_{4}$ and $\mathrm{LiCoMnO}_{4}$ with a spinel-type structure are some of the most promising $5 \mathrm{~V}$ class cathode materials with energy densities of over $600 \mathrm{Wh}$ $\mathrm{kg}^{-1}$ [2,3]. All-solid-state batteries with $\mathrm{Cr}$-doped $\mathrm{LiNi}_{0.5} \mathrm{Mnn}_{1.5} \mathrm{O}_{4}$ and $\mathrm{LiCoMnO}_{4}$ spinel cathodes and oxide-type solid electrolytes, such as $\mathrm{Li}_{3.2} \mathrm{PO}_{3.8} \mathrm{~N}_{0.2}$ and $\mathrm{Li}_{3} \mathrm{PO}_{4}$, have been reported $[3,4]$. However, these all-solid-state batteries have been limited to thin-film battery systems because of the low ionic conductivity of the oxide electrolytes. Recently, sulfide-type solid electrolytes have been reported to exhibit high ionic conductivity of over $10^{-2} \mathrm{~S} \mathrm{~cm}^{-1}[1,5]$. After materials discovery, there 
have been several studies on all-solid-state batteries comprising $4 \mathrm{~V}$ class cathodes and solid sulfide electrolytes for large-scale systems [6,7].

Here, we report on the reversible lithium intercalation from a $\mathrm{LiNi}_{0.5} \mathrm{Mn}_{1.5} \mathrm{O}_{4}$ cathode through a solid sulfide electrolyte $\mathrm{Li}_{10} \mathrm{GeP}_{2} \mathrm{~S}_{12}$. The surface coating of amorphous $\mathrm{LiNbO}_{3}$ on the $\mathrm{LiNi}_{0.5} \mathrm{Mn}_{1.5} \mathrm{O}_{4}$ surface [8] and the formation of oxygen deficiency in $\mathrm{LiNi}_{0.5} \mathrm{Mn}_{1.5} \mathrm{O}_{4}$ [9] were investigated to decrease interfacial resistance between the oxide cathode and sulfide electrolyte. The charge-discharge reaction of the $\mathrm{LiNbO}_{3}$-coated $\mathrm{LiNi}_{0.5} \mathrm{Mn}_{1.5} \mathrm{O}_{4}$ cathode was characterized using an all-solid-state battery with a $\mathrm{Li}_{10} \mathrm{GeP}_{2} \mathrm{~S}_{12}$ solid electrolyte and In-Li alloy anode.

\section{Experimental}

$\mathrm{LiNi}_{0.5} \mathrm{Mn}_{1.5} \mathrm{O}_{4}$ powder (Toda Kogyo; average particle size of $9.5 \mu \mathrm{m}$ and Brunauer-Emmett-Teller surface area of $0.53 \mathrm{~m}^{2} \mathrm{~g}^{-1}$ ) was annealed at 1023, 1073, and $1123 \mathrm{~K}$ for $10 \mathrm{~h}$ in air to form oxygen-deficient $\mathrm{LiNi}_{0.5} \mathrm{Mn}_{1.5} \mathrm{O}_{4-\delta}$ with high electronic conductivity. $\mathrm{LiNi}_{0.5} \mathrm{Mn}_{1.5} \mathrm{O}_{4-\delta}$ surfaces were coated with $\mathrm{LiNbO}_{3}$ using the sol-gel method. Li metal was dissolved in ethanol under dry Ar, and the ethanol solution was mixed with $\mathrm{Nb}_{2}\left(\mathrm{OC}_{2} \mathrm{H}_{5}\right)_{10}$. The $\mathrm{LiNi}_{0.5} \mathrm{Mn}_{1.5} \mathrm{O}_{4-\delta}$ samples were immersed into the solution, which was agitated using a magnetic stirrer. The weight ratios of $\mathrm{LiNbO}_{3}$ to $\mathrm{LiNi}_{0.5} \mathrm{Mn}_{1.5} \mathrm{O}_{4-\delta}$ were 2, 3, and $4 \mathrm{wt} \%$. The coated samples were dried under vacuum atmosphere and then heated at $623 \mathrm{~K}$ for $1 \mathrm{~h}$ in air to remove organic species.

The morphologies and crystal structures were characterized by scanning

electron microscopy (SEM: JEOL, JSM-6610LV) and X-ray diffraction (XRD: Rigaku, 
SmartLab) using $\mathrm{Cu} K \alpha_{1}$ radiation. The electronic conductivity was characterized by direct current (DC) conductivity measurement for the $\mathrm{LiNi}_{0.5} \mathrm{Mn}_{1.5} \mathrm{O}_{4-\delta}$ pellets. Prior to the measurement, Au blocking electrode was coated on both sides of the pellets. A constant voltage of $50 \mathrm{mV}$ was applied to the $\mathrm{Au} / \mathrm{LiNi}_{0.5} \mathrm{Mn}_{1.5} \mathrm{O}_{4-\delta} / \mathrm{Au}$ pellets. The current was recorded after the current reached a constant value to eliminate the contribution of lithium ion diffusion to the electrical conduction. X-ray photoelectron spectroscopy (XPS) was conducted using a chamber system (ULVACPHI, ESCA1700R) with monochromatic $\mathrm{Al} \mathrm{K} \alpha(1486.6 \mathrm{eV})$ radiation to investigate the oxide state of $\mathrm{Mn}$ in the $\mathrm{LiNi}_{0.5} \mathrm{Mn}_{1.5} \mathrm{O}_{4-\delta}$. Peak fitting was conducted assuming a Gaussian-Lorentzian curve fit with a Shirley background correction. The binding energy scale was calibrated by setting the main C 1 s line of adventitious carbon at $284 \mathrm{eV}$. The amount of $\mathrm{LiNbO}_{3}$ coating was determined by inductively coupled plasma emission spectrometry (ICP: Shimadzu, ICPS-8100).

Two-electrode all-solid-state batteries were used to investigate the electrochemical properties of the composite electrode [10]. The cathode composite comprised $\mathrm{LiNi}_{0.5} \mathrm{Mn}_{1.5} \mathrm{O}_{4-\delta}, \mathrm{Li}_{10} \mathrm{GeP}_{2} \mathrm{~S}_{12}$, and acetylene black with a weight ratio of 40:60:4 and it was prepared using a pot mill rotator (Nitto, ANZ-10). Two layers of the cathode composite $(10 \mathrm{mg})$ and $\mathrm{Li}_{10} \mathrm{GeP}_{2} \mathrm{~S}_{12}$ solid electrolyte $(100 \mathrm{mg}$ ) were pressed together in a polycarbonate tube, and then, In-Li alloy as the anode was pressed on the pellet. Charge-discharge measurements were performed using a multichannel potentio/galvanostat (Toyo system, TOSCAT-3100). The current density was $0.05 \mathrm{C}\left(7.3 \mathrm{~mA} \mathrm{~g}^{-1}\right)$ and the cut off voltages were set at 4.4 and $2.9 \mathrm{~V}$ (vs. In-Li) for charge and discharge, respectively. Electrochemical impedance 
spectroscopy was performed to investigate the interfacial resistance between the cathode and the solid electrolyte using an impedance analyzer with an electrochemical interface (Solartron, 1260/1287). The frequency range and the applied potential were $10^{6}-10^{-2} \mathrm{~Hz}$ and $10 \mathrm{mV}$, respectively.

\section{Results and discussion}

Figure 1 shows XRD patterns of uncoated and $\mathrm{LiNbO}_{3}$-coated $\mathrm{LiNi}_{0.5} \mathrm{Mn}_{1.5} \mathrm{O}_{4}$ powders. All the reflections can be indexed on the basis of the cubic spinel structure. Lattice parameters calculated using XRD patterns are 8.170(1), 8.171(1), 8.171(2), and $8.172(2) \AA$ for uncoated, 2 wt. $\%, 3$ wt.\%, and 4 wt.\% LiNbO$_{3}$-coated $\mathrm{LiNi}_{0.5} \mathrm{Mn}_{1.5} \mathrm{O}_{4}$, respectively. There were no changes in the lattice parameters; this revealed that the $\mathrm{LiNbO}_{3}$ coating caused no crystal structure change in the $\mathrm{LiNi}_{0.5} \mathrm{Mn}_{1.5} \mathrm{O}_{4}$ lattice. The analytical weight ratios were smaller than the calculated values, which were calculated from the amount of starting materials (Table 1). This might be due to loss of coating solution during the sol-gel coating process because some amount of coating solution was stuck on the surface of the glass container. The coating thicknesses calculated using the analyzed amount of $\mathrm{LiNbO}_{3}$ and the total surface area of the $\mathrm{LiNi}_{0.5} \mathrm{Mn}_{1.5} \mathrm{O}_{4}$ particles were 6.5, 9.7, and $14.3 \mathrm{~nm}$ for the 2, 3, and $4 \mathrm{wt} \% \mathrm{LiNbO}_{3}$, respectively.

Figure 2 shows the first charge and discharge curves for all-solid-state batteries with uncoated and $\mathrm{LiNbO}_{3}$-coated $\mathrm{LiNi}_{0.5} \mathrm{Mn}_{1.5} \mathrm{O}_{4}$. No electrochemical activity was observed for the uncoated $\mathrm{LiNi}_{0.5} \mathrm{Mn}_{1.5} \mathrm{O}_{4}$. The behavior was similar to that reported previously for batteries with oxide cathodes and solid electrolytes, 
wherein an interfacial layer with high resistance forms at the cathode-solid electrolyte interface [3]. In contrast, the $\mathrm{LiNbO}_{3}$-coated $\mathrm{LiNi}_{0.5} \mathrm{Mn}_{1.5} \mathrm{O}_{4}$ showed charge-discharge activity. A plateau region was observed at approximately $4.0 \mathrm{~V}$ (ca. $4.6 \mathrm{~V}$ vs. $\mathrm{Li} / \mathrm{Li}^{+}$), which corresponds to the $\mathrm{Ni}^{4+} / \mathrm{Ni}^{3+}$ and $\mathrm{Ni}^{3+} / \mathrm{Ni}^{2+}$ redox reactions due to lithium deintercalation from and intercalation into $\mathrm{LiNi}_{0.5} \mathrm{Mn}_{1.5} \mathrm{O}_{4}$.

This result indicates that the $\mathrm{LiNbO}_{3}$-coating layer sufficiently reduced the interfacial resistance between the $\mathrm{LiNi}_{0.5} \mathrm{Mn}_{1.5} \mathrm{O}_{4}$ and the $\mathrm{Li}_{10} \mathrm{GeP}_{2} \mathrm{~S}_{12}$. The discharge capacities were 38,53 , and $26 \mathrm{mAh} \mathrm{g}^{-1}$ for the 6.5, 9.7, and 14.3-nm-LiNbO${ }_{3}$-coated $\mathrm{LiNi}_{0.5} \mathrm{Mn}_{1.5} \mathrm{O}_{4}$, respectively. The increase in capacity for the $9.7 \mathrm{~nm}$ coating compared to the $6.5 \mathrm{~nm}$ coating indicates that the higher coverage of the $\mathrm{LiNbO}_{3}$ layer effectively reduced the interfacial resistance. In contrast, for the 14.3-nm$\mathrm{LiNbO}_{3}$-coated $\mathrm{LiNi}_{0.5} \mathrm{Mn}_{1.5} \mathrm{O}_{4}$, the thick $\mathrm{LiNbO}_{3}$ layer acted as a resistive layer due to the low lithium conductivity of $6 \times 10^{-7}-8 \times 10^{-7} \mathrm{~S} \mathrm{~cm}^{-1}[11]$.

The discharge capacity of the $9.7 \mathrm{~nm}-\mathrm{LiNbO}_{3}$-coated $\mathrm{LiNi}_{0.5} \mathrm{Mn}_{1.5} \mathrm{O}_{4}$ was much smaller than that of the $\mathrm{LiNi}_{0.5} \mathrm{Mn}_{1.5} \mathrm{O}_{4}$ using a liquid-type cell operated under the same voltage window (146 $\mathrm{mAh} \mathrm{g}^{-1}$ ) [2]. One possible reason is the low electronic conductivity of $\mathrm{LiNi}_{0.5} \mathrm{Mn}_{1.5} \mathrm{O}_{4}\left(10^{-6} \mathrm{~S} \mathrm{~cm}^{-1}\right.$ at room temperature) [9], which could increase the resistance of the charge transfer reaction. There are two main ways to improve the reaction rates of intercalation electrodes with low electronic conductivity: (i) decrease the particle size to shorten the diffusion distance for the electrons and to increase the contact area at the electrode/electrolyte interface, which can enhance reaction rates of lithium (de)intercalation [12,13]. (ii) coat conductive carbon on the electrode particles to improve surface electronic 
conductivity [14]. However, any change in particle size and/or surface coating would also change the contact area and the conditions between the electrode and the solid electrolyte, which affects the electrode properties of $\mathrm{LiNi}_{0.5} \mathrm{Mn}_{1.5} \mathrm{O}_{4}$. To investigate the effect of the electronic conductivity on the intercalation properties with a fixed condition of the composite electrode, we controlled the electronic conductivity of $\mathrm{LiNi}_{0.5} \mathrm{Mn}_{1.5} \mathrm{O}_{4}$ by the introduction of oxygen deficiencies using hightemperature annealing in air [9]. No significant changes in shape and size were observed for the $\mathrm{LiNi}_{0.5} \mathrm{Mn}_{1.5} \mathrm{O}_{4-\delta}$ particles after annealing (See Figure S1 in supplemental information), which leads to a similar mixing condition of $\mathrm{LiNi}_{0.5} \mathrm{Mn}_{1.5} \mathrm{O}_{4-\delta}$ with $\mathrm{Li}_{10} \mathrm{GeP}_{2} \mathrm{~S}_{12}$ to that of the unannealed $\mathrm{LiNi}_{0.5} \mathrm{Mn}_{1.5} \mathrm{O}_{4}$.

Figure 3 shows XRD patterns, cell parameters, electronic conductivities, and Ni 2p and Mn 2p XPS spectra of $\mathrm{LiNi}_{0.5} \mathrm{Mn}_{1.5} \mathrm{O}_{4-\delta}$ annealed in air at 1023, 1073, and 1123 K. XRD patterns shifted to lower angles after high-temperature annealing. Cell parameters increased from 8.170(1) Å for the unannealed sample to 8.181(15) and 8.184(12) Å for the $1023 \mathrm{~K}$ and $1073 \mathrm{~K}$ annealed samples, respectively. The increase in the lattice parameter corresponds to the formation of oxygen-deficient $\mathrm{LiNi}_{0.5} \mathrm{Mn}_{1.5} \mathrm{O}_{4-\delta}$ [15], which includes larger $\mathrm{Mn}^{3+}$ ions that were changed from $\mathrm{Mn}^{4+}$ ions in the structure for charge balance. The $1123 \mathrm{~K}$ annealed sample had a much larger cell parameter of 8.205(2) Å. The 222 diffraction peak observed at $38^{\circ}$ had a shoulder at a low-angle region [16]. The formation of the secondary $\mathrm{Li}_{y} \mathrm{Ni}_{1-y} \mathrm{O}$ phase resulted in broad diffraction peaks and an apparently large lattice parameter [15]. To confirm the increase in the $\mathrm{Mn}^{3+}$ content in annealed samples, valance states of $\mathrm{Ni}$ and $\mathrm{Mn}$ ions at the particle surface were analyzed by XPS measurements. The Ni 
$2 p$ peak was observed at $854.8 \mathrm{eV}$ for unannealed and annealed samples, which corresponded to the oxidation state of $2+[17]$. The Mn $2 p$ peaks contained the two components $\mathrm{Mn}^{3+}$ and $\mathrm{Mn}^{4+}$ observed at 641.9 and $643.2 \mathrm{eV}$, respectively [17]. The charge-discharge curves shown in Figure 2 exhibited no redox reaction of $\mathrm{Mn}^{4+} / \mathrm{Mn}^{3+}$, which clarified the tetravalent oxidation state of $\mathrm{Mn}$ in the pristine $\mathrm{LiNi}_{0.5} \mathrm{Mn}_{1.5} \mathrm{O}_{4}$ [18]. Considering that the escape depth of a photoelectron is very small $(\sim 1 \mathrm{~nm})$, trivalent Mn could exist only at the electrode surface for unannealed $\mathrm{LiNi}_{0.5} \mathrm{Mn}_{1.5} \mathrm{O}_{4}$. It has been reported that the $\mathrm{LiNi}_{0.5} \mathrm{Mn}_{1.5} \mathrm{O}_{4}$ surface reacts with moisture and carbon dioxide in air, which leads to the reduction from $\mathrm{Mn}^{4+}$ to $\mathrm{Mn}^{3+}$ [19], which is consistent with the existence of $\mathrm{Mn}^{3+}$ in the unannealed sample. The intensity ratio of $\mathrm{Mn}^{3+}$ to $\mathrm{Mn}^{4+}$ peaks gradually increased with the increase in the annealing temperature, which indicates the further reduction from $\mathrm{Mn}^{4+}$ to $\mathrm{Mn}^{3+}$ by the formation of oxygen vacancies at high-temperature annealing. Electronic conductivities of $\mathrm{LiNi}_{0.5} \mathrm{Mn}_{1.5} \mathrm{O}_{4-\delta}$ annealed at 1023 and $1073 \mathrm{~K}$ were $7.6 \times 10^{-4}$ and $8.9 \times 10^{-4} \mathrm{~S} \mathrm{~cm}^{-1}$, respectively, which are higher than that of unannealed $\mathrm{LiNi}_{0.5} \mathrm{Mn}_{1.5} \mathrm{O}_{4}\left(5.6 \times 10^{-6} \mathrm{~S} \mathrm{~cm}^{-1}\right)$. The increase in the $\mathrm{Mn}^{3+}$ content in the spinel lattice stimulates electron hopping between $\mathrm{Mn}^{3+}$ and $\mathrm{Mn}^{4+}$, which causes a high electronic conductivity in oxygen-deficient $\mathrm{LiNi}_{0.5} \mathrm{Mn}_{1.5} \mathrm{O}_{4-\delta}[20,21]$. A slight decrease in the conductivity was observed for the $1123 \mathrm{~K}$ annealed sample $\left(4.8 \times 10^{-4} \mathrm{~S} \mathrm{~cm}^{-1}\right)$, which could be related to the formation of the secondary phase detected by the XRD.

Figure 4 shows the first discharge curves for an all-solid-state battery with $\mathrm{LiNi}_{0.5} \mathrm{Mn}_{1.5} \mathrm{O}_{4-\delta}$ annealed at various temperatures. All samples were coated by $3 \mathrm{wt} \%$ $\mathrm{LiNbO}_{3}$ after high-temperature annealing. $\mathrm{LiNi}_{0.5} \mathrm{Mn}_{1.5} \mathrm{O}_{4-\delta}$ annealed at 1023 and 
$1073 \mathrm{~K}$ showed a higher capacity at a $4 \mathrm{~V}$ plateau region. Furthermore, in the annealed sample, plateaus were observed at a high-voltage region compared with the unannealed sample. These results indicate that the high electronic conductivity of $\mathrm{LiNi}_{0.5} \mathrm{Mn}_{1.5} \mathrm{O}_{4-\delta}$ improved lithium intercalation into $\mathrm{LiNi}_{0.5} \mathrm{Mn}_{1.5} \mathrm{O}_{4}$ through the $\mathrm{Li}_{10} \mathrm{GeP}_{2} \mathrm{~S}_{12}$ solid electrolyte. In addition to the $4 \mathrm{~V}$ plateau region, another plateau was observed at approximately $3.4 \mathrm{~V}$ for $\mathrm{LiNi}_{0.5} \mathrm{Mn}_{1.5} \mathrm{O}_{4-\delta}$, which could be attributed to lithium intercalation accompanied by the reduction from $\mathrm{Mn}^{4+}$ to $\mathrm{Mn}^{3+}$ that has been generally observed for $\mathrm{LiNi}_{0.5} \mathrm{Mn}_{1.5} \mathrm{O}_{4-\delta}$ in lithium ion batteries with organic liquid electrolytes [18]. The discharge capacity of the $3.4 \mathrm{~V}$ plateau increased with the annealing temperature. This is in agreement with the higher $\mathrm{Mn}^{3+} / \mathrm{Mn}^{4+}$ ratio in $\mathrm{LiNi}_{0.5} \mathrm{Mn}_{1.5} \mathrm{O}_{4-\delta}$ annealed at a higher temperature, which was indicated by XRD and XPS results. Total discharge capacities of $\mathrm{LiNi}_{0.5} \mathrm{Mn}_{1.5} \mathrm{O}_{4-\delta}$ annealed at 1023 and 1073 $\mathrm{K}$ were 69 and $80 \mathrm{mAh} \mathrm{g}^{-1}$, respectively, which were higher than that of the unannealed $\mathrm{LiNi}_{0.5} \mathrm{Mn}_{1.5} \mathrm{O}_{4}\left(53 \mathrm{mAh} \mathrm{g}^{-1}\right.$ ). In contrast to the 1023 and $1073 \mathrm{~K}$ annealed samples, $\mathrm{LiNi}_{0.5} \mathrm{Mn}_{1.5} \mathrm{O}_{4-\delta}$ annealed at $1123 \mathrm{~K}$ showed a small capacity of 38 mAh g-1 The small capacity could be caused by the poor electrochemical activity of the secondary phases such as $\mathrm{Li}_{1-\mathrm{y}} \mathrm{Ni}_{\mathrm{y}} \mathrm{O}, \mathrm{Li}_{2} \mathrm{MnO}_{3}$, and $\mathrm{Mn}_{2} \mathrm{O}_{3}[16]$.

Figure 5 shows the electrochemical impedance spectra of the all-solid-state batteries with $\mathrm{LiNbO}_{3}$-coated $\mathrm{LiNi}_{0.5} \mathrm{Mn}_{1.5} \mathrm{O}_{4-\delta}$ after the first charging to $4.1 \mathrm{~V}$. A semicircle with a low frequency of approximately $10 \mathrm{~Hz}$ was observed for all batteries. Considering that the $\mathrm{Li}-\mathrm{In} / \mathrm{Li}_{10} \mathrm{GeP}_{2} \mathrm{~S}_{12}$ interfaces were fabricated by the same condition, changes in cell resistances should be related to the reactions at the $\mathrm{LiNi}_{0.5} \mathrm{Mn}_{1.5} \mathrm{O}_{4-\delta} / \mathrm{Li}_{10} \mathrm{GeP}_{2} \mathrm{~S}_{12}$ interfaces. The resistances calculated from the 
semicircles were 1873 and $870 \Omega$ for $\mathrm{LiNi}_{0.5} \mathrm{Mn}_{1.5} \mathrm{O}_{4-\delta}$ synthesized at 1023 and 1073 $\mathrm{K}$, respectively, which were smaller than those of unannealed $\mathrm{LiNi}_{0.5} \mathrm{Mn}_{1.5} \mathrm{O}_{4}$ (3377 $\Omega$ ). This result indicates that the $\mathrm{LiNi}_{0.5} \mathrm{Mn}_{1.5} \mathrm{O}_{4-\delta}$ with high electronic conductivity decreases the charge transfer resistance at the $\mathrm{LiNi}_{0.5} \mathrm{Mn}_{1.5} \mathrm{O}_{4-\delta} / \mathrm{Li}_{10} \mathrm{GeP}_{2} \mathrm{~S}_{12}$ interface.

Figure 6 shows the capacity retention of all-solid-state batteries using unannealed $\mathrm{LiNi}_{0.5} \mathrm{Mn}_{1.5} \mathrm{O}_{4}$ and $\mathrm{LiNi}_{0.5} \mathrm{Mn}_{1.5} \mathrm{O}_{4-\delta}$ annealed at various temperatures. The discharge capacities decreased with voltage fading during the initial 5 cycles, independently of the annealing condition. $\mathrm{LiNi}_{0.5} \mathrm{Mn}_{1.5} \mathrm{O}_{4-\delta}$ annealed at $1073 \mathrm{~K}$ showed the capacity retention at the twentieth cycle of $43.9 \%$ of the first discharge capacity. Oxygen-deficient $\mathrm{LiNi}_{0.5} \mathrm{Mn}_{1.5} \mathrm{O}_{4-\delta}$ has been reported to be unsuitable for practical use in liquid-type lithium batteries because two $\mathrm{Mn}^{3+}$ ions undergo disproportionation to $\mathrm{Mn}^{2+}$ and $\mathrm{Mn}^{4+}$ ions, followed by dissolution of $\mathrm{Mn}^{2+}$ into the liquid electrolyte [22,23]. As the conductivity of manganese ions in a solid electrolyte should be negligibly small, the electrode fading caused by the disproportionation is expected to be suppressed at solid/solid interfaces. No significant impact of the oxygen deficiency on the cycle retention was observed, which agrees with this expectation. Furthermore, the all solid-state batteries with $\mathrm{LiNi}_{0.5} \mathrm{Mn}_{1.5} \mathrm{O}_{4-\delta}$ showed the small voltage fading upon the cycles, compared to batteries with conventional organic electrolytes $[22,23]$. Thus, we presume that the fading is associated with side reactions between the electrode and solid electrolyte interfaces such as decomposition of the coating layer and/or the solid electrolyte at high voltages. Further understanding of the interfacial reactions could be crucial to 
develop high-voltage all solid-state batteries with oxygen-deficient $\mathrm{LiNi}_{0.5} \mathrm{Mn}_{1.5} \mathrm{O}_{4-\delta}$.

\section{Conclusion}

Intercalation activity of spinel-type $\mathrm{LiNi}_{0.5} \mathrm{Mn}_{1.5} \mathrm{O}_{4}$ cathodes through the $\mathrm{Li}_{10} \mathrm{GeP}_{2} \mathrm{~S}_{12}$ solid electrolyte has been investigated using a bulk-type all-solid-state battery. The surface coating of $\mathrm{LiNbO}_{3}$ on $\mathrm{LiNi}_{0.5} \mathrm{Mn}_{1.5} \mathrm{O}_{4}$ is an effective method to form an electrochemically active interface with the $\mathrm{Li}_{10} \mathrm{GeP}_{2} \mathrm{~S}_{12}$ electrolyte. The

oxygen-deficient $\mathrm{LiNi}_{0.5} \mathrm{Mn}_{1.5} \mathrm{O}_{4-\delta}$ phases deliver higher charge and discharge capacities than stoichiometric $\mathrm{LiNi}_{0.5} \mathrm{Mn}_{1.5} \mathrm{O}_{4}$. An all-solid-state battery consisting of $\mathrm{LiNbO}_{3}$-coated $\mathrm{LiNi}_{0.5} \mathrm{Mn}_{1.5} \mathrm{O}_{4-\delta} / \mathrm{Li}_{10} \mathrm{GeP}_{2} \mathrm{~S}_{12} / \mathrm{In}$-Li achieves a discharge capacity of 80 mAh g-1 with an average voltage of $4.1 \mathrm{~V}$ at the first cycle. Surface modification by the $\mathrm{LiNbO}_{3}$ coating and the introduction of oxygen deficiency is a key to improve the lithium intercalation properties of the $\mathrm{LiNi}_{0.5} \mathrm{Mn}_{1.5} \mathrm{O}_{4}$ cathode through the $\mathrm{Li}_{10} \mathrm{GeP}_{2} \mathrm{~S}_{12}$ solid electrolyte.

\section{Acknowledgements}

We would like to thank Professors T. Baba and K. Motokura of the Tokyo Institute of Technology for their kind assistance in measuring XPS spectra. This work was supported by a Grant-in-Aid from the Advanced Low Carbon Technology Research and Development Program (ALCA) of the Japan Science and Technology Agency (JST). We also thank the analysis center of Suzukakedai campus of the Tokyo Institute of Technology for SEM/EDS and ICP. 


\section{References}

[1] N. Kamaya, K. Homma, Y. Yamakawa, M. Hirayama, R. Kanno, M. Yonemura, T. Kamiyama, Y. Kato, S. Hama, K. Kawamoto, A. Mitsui, Nat. Mater. 10 (2011) 682686.

[2] G.Q. Liu, L. Wen, Y.M. Liu, J. Solid State Electrochem. 14 (2010) 2191-2202.

[3] C. Yada, A. Ohmori, K. Ide, H. Yamasaki, T. Kato, T. Saito, F. Sagane, Y. Iriyama, Adv. Energy Mater. 4 (2014) 1301416-1301420.

[4] N. Kuwata, S. Kudo, Y. Matsuda, J. Kawamura, Solid State Ion. 262 (2014) 165169.

[5] Y. Seino, T. Ota, K. Takada, A. Hayashi, M. Tatsumisago, Energy Env. Sci 7 (2014) 627-631.

[6] N. Ohta, K. Takada, L. Zhang, R. Ma, M. Osada, T. Sasaki, Adv. Mater. 18 (2006) 2226-2229.

[7] Y. Seino, T. Ota, K. Takada, J. Power Sources 196 (2011) 6488-6492.

[8] N. Ohta, K. Takada, I. Sakaguchi, L. Zhang, R. Ma, K. Fukuda, M. Osada, T. Sasaki, Electrochem. Commun. 9 (2007) 1486-1490.

[9] M. Kunduraci, G.G. Amatucci, J. Electrochem. Soc. 153 (2006) A1345-A1352.

[10] W.J. Li, M. Hirayama, K. Suzuki, R. Kanno, Solid State Ion. 10.1016/j.ssi.2015.05.007.

[11] A.M. Glass, K. Nassau, T.J. Negran, J. Appl. Phys. 49 (1978) 4808-4811.

[12] Y.-G. Guo, J.-S. Hu, L.-J. Wan, Adv. Mater. 20 (2008) 2878-2887.

[13] J.C. Arrebola, A. Caballero, M. Cruz, L. Hernán, J. Morales, E.R. Castellón, Adv. Funct. Mater. 16 (2006) 1904-1912.

[14] T. Yang, N. Zhang, Y. Lang, K. Sun, Electrochimica Acta 56 (2011) 4058-4064.

[15] M. Kunduraci, J.F. Al-Sharab, G.G. Amatucci, Chem. Mater. 18 (2006) 35853592.

[16] T. Yang, K. Sun, Z. Lei, N. Zhang, Y. Lang, J. Alloys Compd. 502 (2010) 215219.

[17] J.S. Park, K.C. Roh, J.-W. Lee, K. Song, Y.-I. Kim, Y.-M. Kang, J. Power Sources 230 (2013) 138-142.

[18] J. Zheng, J. Xiao, X. Yu, L. Kovarik, M. Gu, F. Omenya, X. Chen, X.-Q. Yang, J. Liu, G.L. Graff, M.S. Whittingham, J.-G. Zhang, Phys. Chem. Chem. Phys. 14 (2012) $13515-13521$.

[19] H. Konishi, K. Suzuki, S. Taminato, K. Kim, S. Kim, J. Lim, M. Hirayama, R. Kanno, J. Power Sources 246 (2014) 365-370.

[20] M. Atanasov, J.-L. Barras, L. Benco, C. Daul, J. Am. Chem. Soc. 122 (2000) $4718-4728$.

[21] K. Tateishi, D. du Boulay, N. Ishizawa, Appl. Phys. Lett. 84 (2004) 529-531.

[22] Y.K. Sun, Y.S. Lee, M. Yoshio, K. Amine, Electrochem. Solid-State Lett. 5 (2002) A99-A102.

[23] X. Fang, N. Ding, X.Y. Feng, Y. Lu, C.H. Chen, Electrochimica Acta 54 (2009) 7471-7475. 


\section{Tables}

Table 1. Fractions of $\mathrm{LiNbO}_{3}$ in starting materials and products and average layer thicknesses.

\begin{tabular}{cccc}
\hline Fraction of $\mathrm{LiNbO}_{3}$ in starting material & $2 \mathrm{wt} \%$ & $3 \mathrm{wt} \%$ & $4 \mathrm{wt} \%$ \\
Fraction of $\mathrm{LiNbO}_{3}$ in product & $1.6 \mathrm{wt} \%$ & $2.4 \mathrm{wt} \%$ & $3.5 \mathrm{wt} \%$ \\
Average thickness of $\mathrm{LiNbO}_{3}$ on particles & $6.5 \mathrm{~nm}$ & $9.7 \mathrm{~nm}$ & $14.3 \mathrm{~nm}$ \\
\hline
\end{tabular}

\section{Figure captions}

Figure 1. XRD patterns of uncoated and 2, 3, and 4 wt $\% \mathrm{LiNbO}_{3}$-coated $\mathrm{LiNi}_{0.5} \mathrm{Mn}_{1.5} \mathrm{O}_{4}$.

Figure 2. The first charge and discharge curves of all-solid-state batteries with uncoated and $\mathrm{LiNbO}_{3}$-coated $\mathrm{LiNi}_{0.5} \mathrm{Mn}_{1.5} \mathrm{O}_{4}$.

Figure 3. XRD patterns, cell parameters, electric conductivities, and XPS spectra of (a) unannealed $\mathrm{LiNi}_{0.5} \mathrm{Mn}_{1.5} \mathrm{O}_{4}$ and $\mathrm{LiNi}_{0.5} \mathrm{Mn}_{1.5} \mathrm{O}_{4-\delta}$ annealed at (b) 1023, (c) 1073, and (d) $1123 \mathrm{~K}$ in air.

Figure 4. The first discharge curves of all-solid-state batteries using unannealed $\mathrm{LiNi}_{0.5} \mathrm{Mn}_{1.5} \mathrm{O}_{4}$ and $\mathrm{LiNi}_{0.5} \mathrm{Mn}_{1.5} \mathrm{O}_{4-\delta}$ annealed at various temperatures. All samples were coated with $3 \mathrm{wt} \% \mathrm{LiNbO}_{3}$ layer after annealing. The In-Li alloy was used as an anode, and the current density was $0.05 \mathrm{C}$.

Figure 5. Nyquist plots of the all-solid-state batteries with $3 \mathrm{wt} \% \mathrm{LiNbO}_{3}$-coated $\mathrm{LiNi}_{0.5} \mathrm{Mn}_{1.5} \mathrm{O}_{4-\delta}$ after the first charging to $4.1 \mathrm{~V}$.

Figure 6. Variation of discharge capacities with cycle number for all-solid-state batteries using unannealed $\mathrm{LiNi}_{0.5} \mathrm{Mn}_{1.5} \mathrm{O}_{4}$ and $\mathrm{LiNi}_{0.5} \mathrm{Mn}_{1.5} \mathrm{O}_{4-\delta}$ annealed at various temperatures. All samples were coated with $3 \mathrm{wt} \% \mathrm{LiNbO}_{3}$ layer 
after annealing. The In-Li alloy was used as an anode, and the current density was $0.05 \mathrm{C}$. Inset depicts the discharge curves of $1073 \mathrm{~K}$-annealed $\operatorname{LiNi}_{0.5} \mathrm{Mn}_{1.5} \mathrm{O}_{4-\delta}$. 


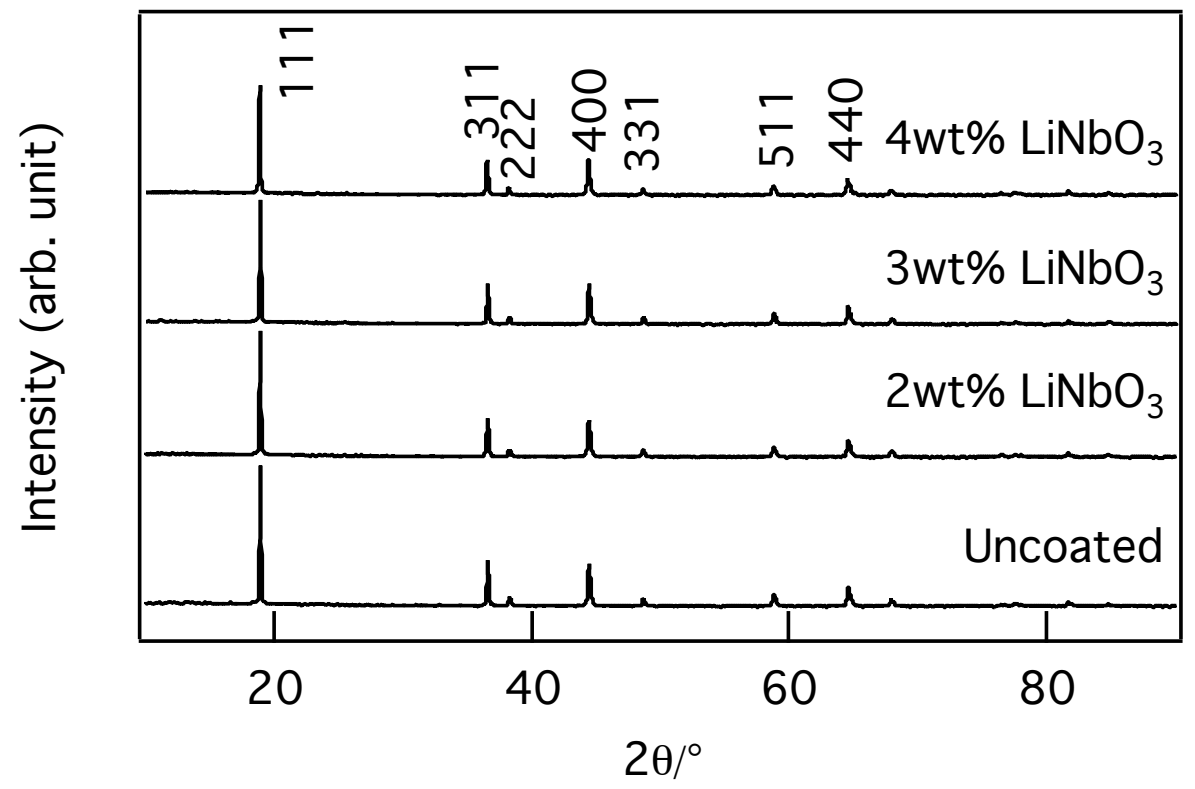

Figure 1. XRD patterns of uncoated and 2, 3, and $4 \mathrm{wt} \% \mathrm{LiNbO}_{3}$-coated $\mathrm{LiNi}_{0.5} \mathrm{Mn}_{1.5} \mathrm{O}_{4}$. 


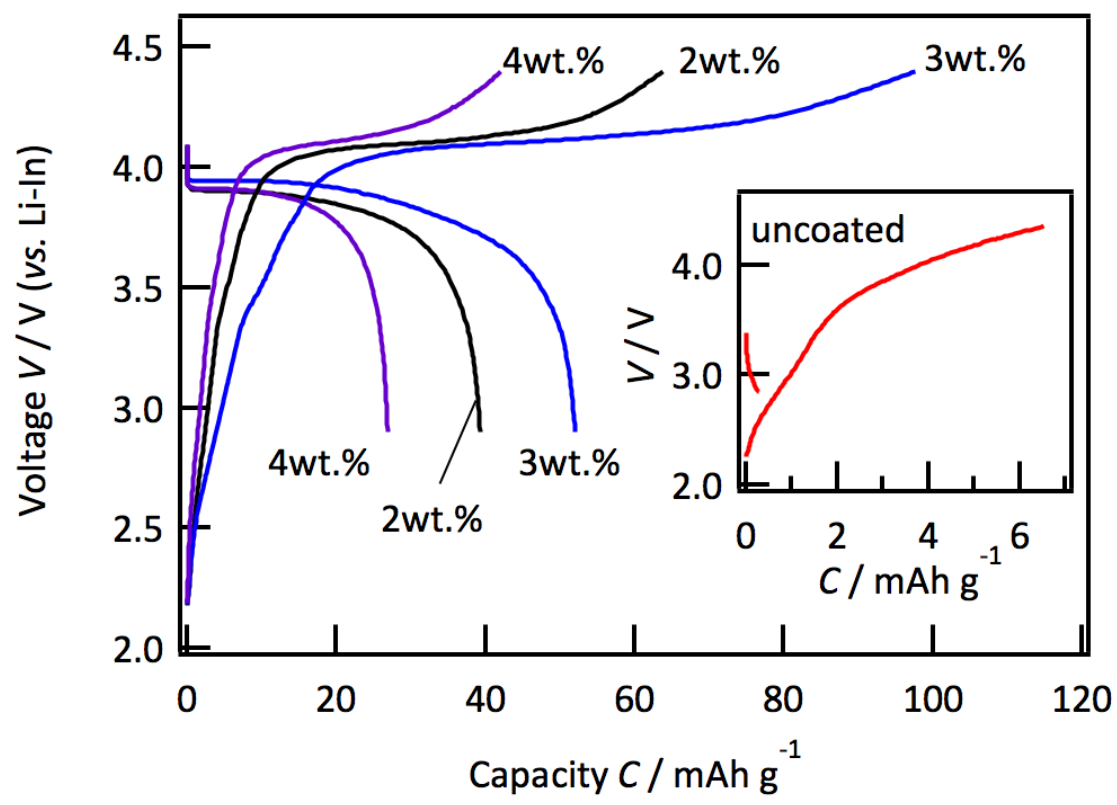

Figure 2. The first charge and discharge curves of all-solid-state batteries with uncoated and $\mathrm{LiNbO}_{3}$-coated $\mathrm{LiNi}_{0.5} \mathrm{Mn}_{1.5} \mathrm{O}_{4}$. 

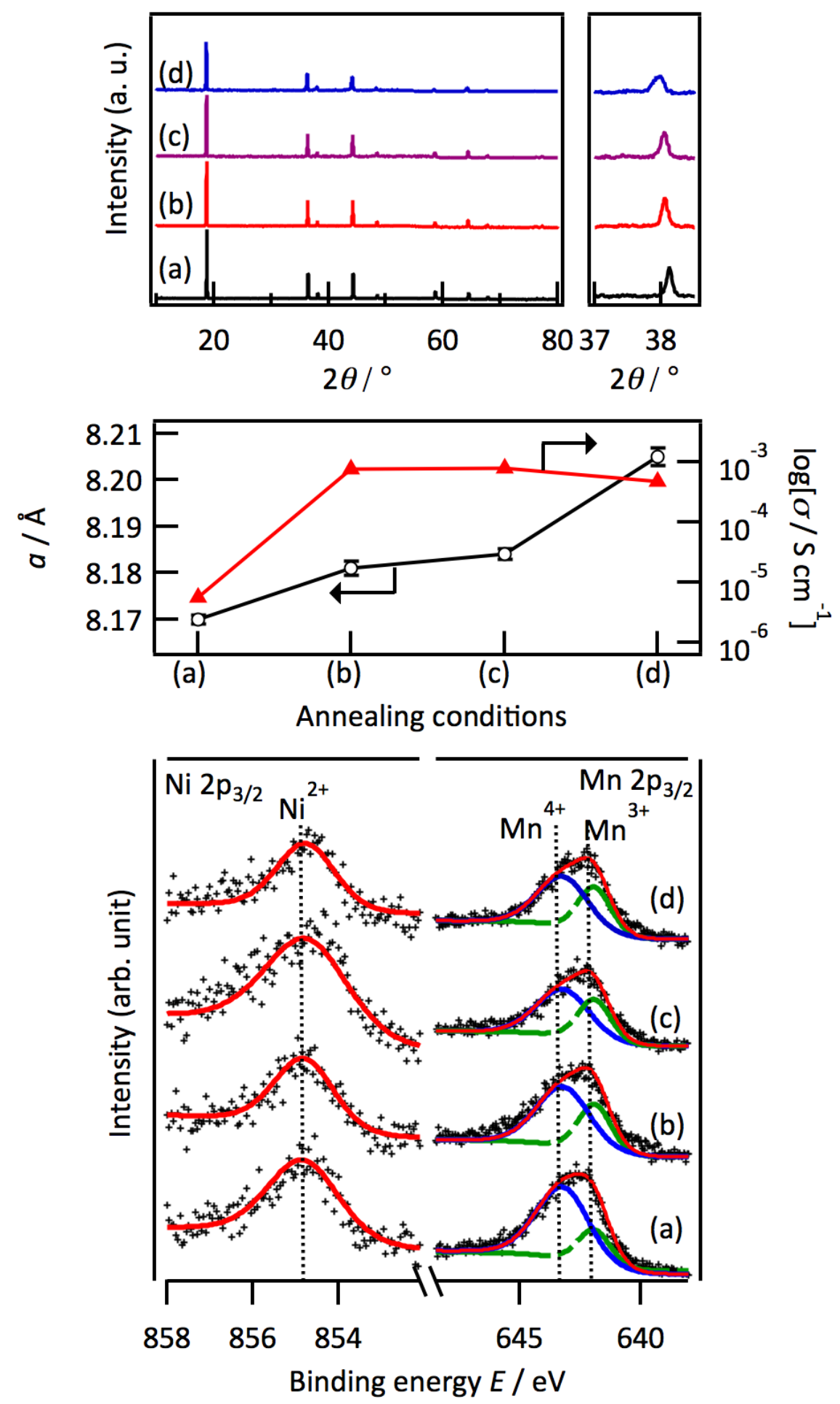

Figure 3. XRD patterns, cell parameters, electric conductivities, and XPS spectra of (a) unannealed $\mathrm{LiNi}_{0.5} \mathrm{Mn}_{1.5} \mathrm{O}_{4}$ and $\mathrm{LiNi}_{0.5} \mathrm{Mn}_{1.5} \mathrm{O}_{4-\delta}$ annealed at (b) 1023, (c) 1073, and (d) $1123 \mathrm{~K}$ in air. 


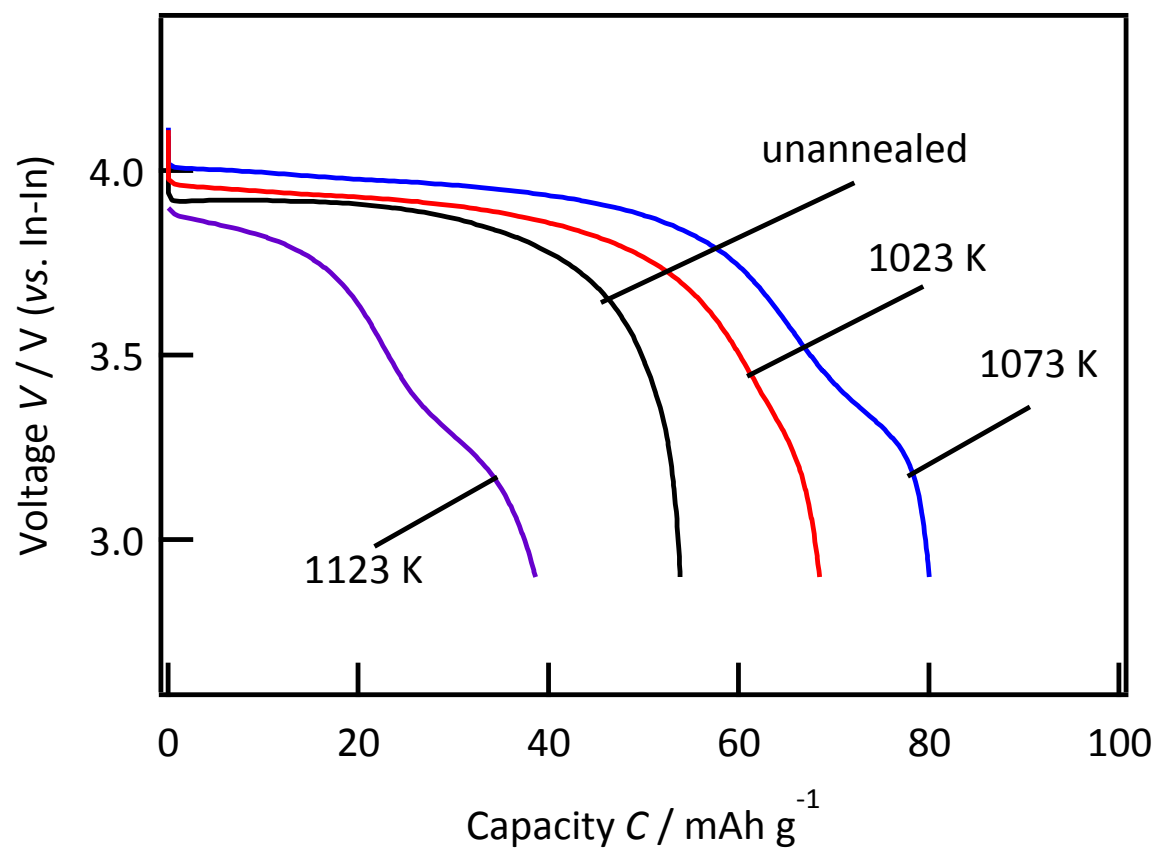

Figure 4. The first discharge curves of all-solid-state batteries using unannealed $\mathrm{LiNi}_{0.5} \mathrm{Mn}_{1.5} \mathrm{O}_{4}$ and $\mathrm{LiNi}_{0.5} \mathrm{Mn}_{1.5} \mathrm{O}_{4-\delta}$ annealed at various temperatures. All samples were coated with $3 \mathrm{wt} \% \mathrm{LiNbO}_{3}$ layer after annealing. The In-Li alloy was used as an anode, and the current density was $0.05 \mathrm{C}$. 


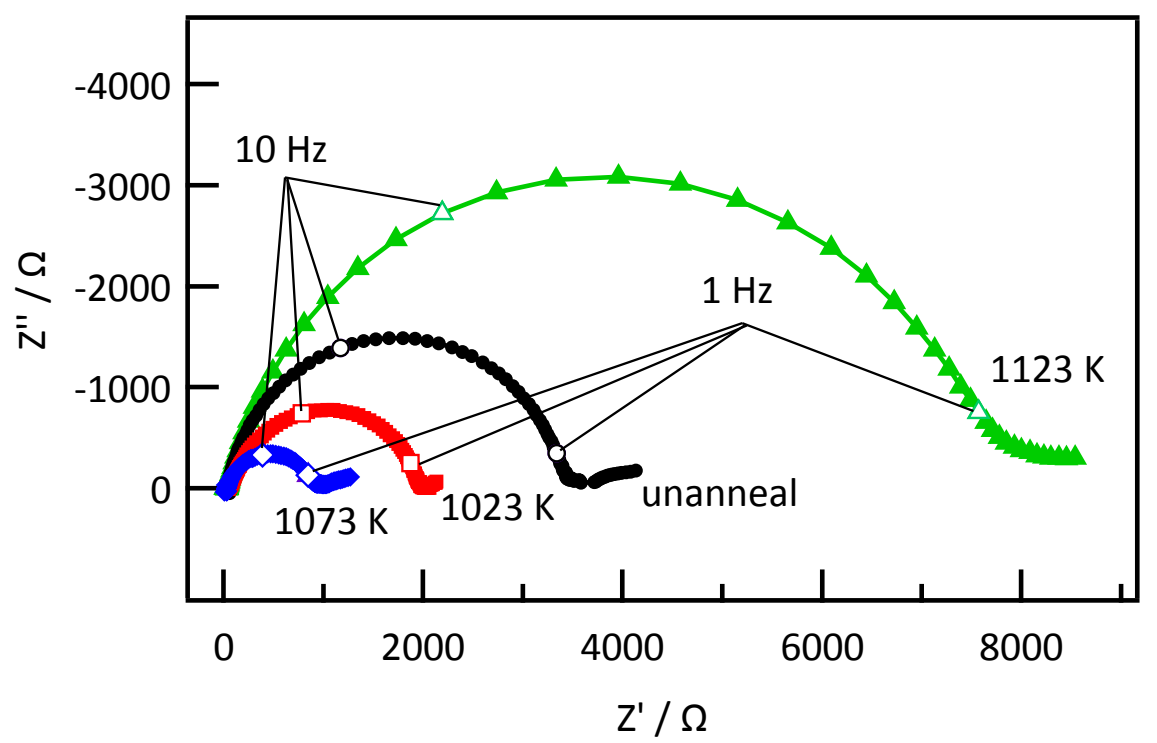

Figure 5. Nyquist plots of the all-solid-state batteries with $3 \mathrm{wt} \% \mathrm{LiNbO}_{3}$-coated $\mathrm{LiNi}_{0.5} \mathrm{Mn}_{1.5} \mathrm{O}_{4-\delta}$ after the first charging to $4.1 \mathrm{~V}$. 


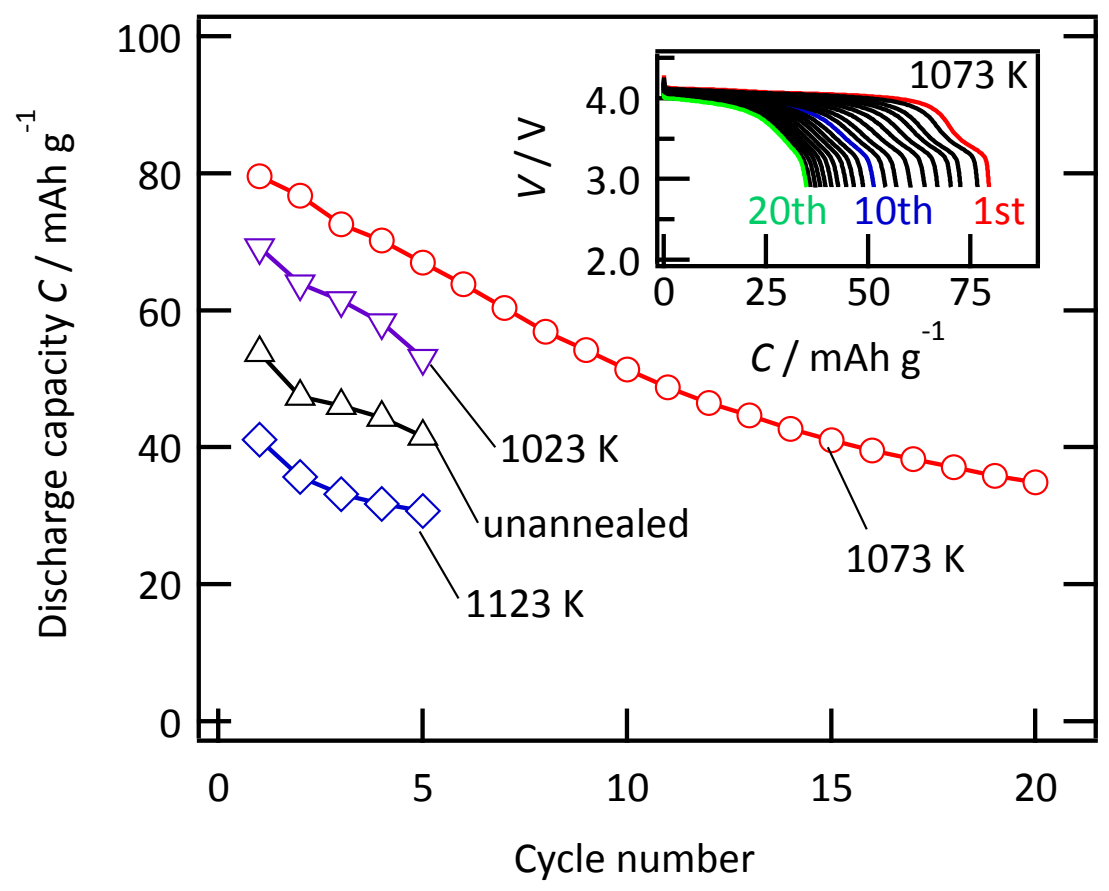

Figure 6. Variation of discharge capacities with cycle number for all-solid-state batteries using unannealed $\mathrm{LiNi}_{0.5} \mathrm{Mn}_{1.5} \mathrm{O}_{4}$ and $\mathrm{LiNi}_{0.5} \mathrm{Mn}_{1.5} \mathrm{O}_{4-\delta}$ annealed at various temperatures. All samples were coated with $3 \mathrm{wt} \% \mathrm{LiNbO}_{3}$ layer after annealing. The In-Li alloy was used as an anode, and the current density was $0.05 \mathrm{C}$. Inset depicts the discharge curves of $1073 \mathrm{~K}$-annealed $\mathrm{LiNi}_{0.5} \mathrm{Mn}_{1.5} \mathrm{O}_{4-\delta}$. 